\title{
Functional inactivation of the oestrogen receptor by the antioestrogen, ZM 182780, sensitises tumour cells to reactive oxygen species
}

\author{
C J Newton ${ }^{1}$, N Drummond ${ }^{1}$, C H Burgoyne ${ }^{1}$, V Speirs ${ }^{1}$, \\ G K Stalla ${ }^{2}$ and $\mathbf{S}$ L Atkin ${ }^{1}$ \\ ${ }^{1}$ Department of Endocrinology and Diabetes, University of Hull, Hull HU6 7RX, UK \\ ${ }^{2}$ Max-Planck Institute of Psychiatry, Munich, Germany \\ (Requests for offprints should be addressed to C J Newton, Medical Research Laboratory, Wolfson Building, University of Hull, Cottingham Road, \\ Hull HU6 7RX)
}

\begin{abstract}
Reactive oxygen species (ROS) play a fundamental role in both apoptotic and necrotic cell death. Their importance is highlighted by studies showing that they mediate cell death in response to radiotherapy and to some forms of chemotherapy. Here we provide the first evidence for a role of ROS in response to an antiendocrine agent currently undergoing clinical trials. Using the oestrogen receptor (ER) containing rat pituitary $\mathrm{GH}_{3}$ cell line, we show that cell death is induced by the pure steroidal antioestrogen, ZM 182780, and that this is blocked by the antioxidant, $\mathrm{N}$-acetyl cysteine (NAC). By flow cytometry, we show that, prior to the onset of DNA breakdown measured by ELISA, ZM 182780 exposure has no
\end{abstract}

significant effect on intracellular oxidant concentrations. In contrast, ZM 182780 exposure greatly increases sensitivity to oxidants generated by blocking cellular antioxidant pathways and from exogenous administration of hydrogen peroxide $\left(\mathrm{H}_{2} \mathrm{O}_{2}\right)$. As both necrosis and apoptosis are controlled by mitochondrial function, further experiments conducted to determine mitochondrial membrane potential $\left(\Delta \Psi_{\mathrm{m}}\right)$ have indicated that the ZM 182780-induced loss of ER function increases the ease with which oxidants collapse mitochondrial activity and, as a consequence, cell death.

Journal of Endocrinology (1999) 161, 199-210

\section{Introduction}

The oestrogen receptor is a ligand activated transcription factor that, in a number of oestrogen target tissues such as the breast (Katzenellenbogen et al. 1979) and the pituitary (Wiklund \& Gorski 1982, Nowakowski \& Maurer 1994), is responsible for altering growth and function. It is the ability of oestrogens acting via the ER to induce growth of breast tumour cell lines that has provided the drive for the development of ligands that block the transcriptional function of the ER. Tamoxifen was first identified as an antioestrogen over 3 decades ago and is now one of the most widely used medical therapies for breast cancer. Studies over the years have demonstrated that tamoxifen will act as a tissue- and gene-specific oestrogen/antioestrogen (Ramkumar \& Adler 1995). Indeed, in recent years, this agonist/antagonist rheostat property of the ER has been exploited by the synthesis of selective oestrogen receptor modulators (SERMs), compounds that are organ- and gene-specific oestrogens (McDonnell 1995). The ability of tamoxifen and other SERMs to act as tissueand gene-specific oestrogens may in part stem from the presence of a recently identified second form of the ER, the ER $\beta$ (Paech et al. 1997, Kuiper \& Gustafsson 1997). This receptor is promiscuous and in addition to binding to oestrogen response element, in the presence of tamoxifen, it will activate transcription of genes containing the activator protein-1 response element (Paech et al. 1997). For some ER containing organs such as the endometrium, this is an undesirable consequence of 'antioestrogen' action (Decensi et al. 1996). In contast to the SERMs, 'pure antioestrogens' like ZM 182780 (Wakeling et al. 1991, Parker 1993) are being developed. This compound is now undergoing clinical trials (Howell 1997) and has no identified ability to activate transcription through the $\operatorname{ER} \alpha$ or the ER $\beta$. The mechanism of action of pure antioestrogens is thought to be due in part to their ability to enhance proteolytic degradation of the ER as well as their ability to interfere with the transactivation function of the receptor (Gibson et al. 1991, Beckman et al. 1993). It can be considered, therefore, that pure antioestrogens give as near a functional inactivation of ER transcriptional activity as can be obtained by the genetic 'knock-out' of ER expression. 
Our studies on the role played by the ER in cell growth and function have focused on the effects of ZM 182780 in $\mathrm{GH}_{3}$ pituitary tumour cells. These ER containing cells have been shown to be variably responsive to oestogens for growth (Riss \& Sirbasku 1989, Zhou-Li et al. 1992), a finding that is explained by our studies showing that the ER mediates growth induced by oestrogens, growth factors (Newton et al. 1994a,b) and cytokine pathways (Newton et al. 1994c). With reporter genes for the ER, we have shown that the transcriptional activity of the ER is increased by oestrogens and growth factors and this is completely blocked by the pure antioestrogen, ZM 182780. In contrast to these studies conducted under serum free conditions, in medium containing serum, we have observed that ZM 182780 induces death of $\mathrm{GH}_{3}$ cells, with some of the characteristics of apoptosis (Newton 1995). Indeed, experiments on normal rat pituitary cells have demonstrated a clear ability of functional ER ablation by ZM 182780 to induce an apparent cell loss (Newton et al. 1996). Given the potential importance of these findings with regard to the treatment of oestrogen dependent tumours, such as those of the pituitary and indeed those of the breast, we have sought to determine the mechanism for this effect. Most recently we have provided evidence that ZM 182780 enhances sensitivity to gamma irradiation of breast tumour cells (Newton et al. 1998). As it is well established that reactive oxygen species (ROS) are mediators of radiation-induced cell death (Datta et al. 1992), we have sought to determine the role that these agents play in the death of cells due to functional ER ablation by ZM 182780. Our data presented in the current report support the idea that ZM 182780 kills $\mathrm{GH}_{3}$ cells by increasing their sensitivity to ROS.

\section{Materials and Methods}

\section{Reagents}

All reagents for cell culture were obtained from Life Technologies (Paisley, UK). The cell death ELISA and lactate dehydrogenase assays were obtained from Boehringer Mannheim UK (Lewes, UK). Fluorescent probes for flow cytometry were obtained from Molecular Probes (Cambridge Bioscience, UK). Other flow cytometry reagents were obtained from Beckton Dickinson UK Ltd. All other reagents were obtained from Sigma-Aldrich Company Ltd (Poole, Dorset, UK). The pure antioestrogen was obtained as a gift from Zeneca Pharmaceuticals Ltd (Macclesfield, UK). Oestradiol, ZM 182780 and fluorescent probes were dissolved in ethanol to give ethanol concentrations within the culture medium of less than $0 \cdot 1 \%$.

\section{Cell culture}

Pituitary $\mathrm{GH}_{3}$ cells as previously described (Newton et al. 1994a) were maintained in Dulbecco's modified Eagle's medium (DMEM) with phenol red, penicillin $(50 \mathrm{U} / \mathrm{ml})$, streptomycin $(50 \mu \mathrm{g} / \mathrm{ml})$, amphoteracin $(2 \mu \mathrm{g} / \mathrm{ml})$ and $10 \%$ foetal calf serum (GIBCO, Myoclone). For the majority of studies reported here, experiments were conducted on cells seeded into 48 well culture plates at densities over the range 4000 to 10000 cells per $\mathrm{cm}^{2}$. Cells were kept at $37{ }^{\circ} \mathrm{C}$ in an atmosphere of $5 \% \mathrm{CO}_{2}$ in air or for some studies in a relative hypoxia incubator where $\mathrm{O}_{2}$ concentrations were reduced (by the addition of nitrogen) from $21 \%$ to $5 \%$. Prior to treatments, cells were allowed to attach for $24 \mathrm{~h}$.

For flow cytometry, cells were harvested from $75 \mathrm{~cm}^{2}$ culture flasks by the addition of trypsin/EDTA and resuspended in culture medium. These cells were treated in suspension at $37^{\circ} \mathrm{C}$ in a gas atmosphere of $5 \% \mathrm{CO}_{2}$ in air.

\section{Fluorescence microscopy}

To confirm the integrity of cell membranes, a mixture of propidium iodide (PI) and Hoechst 33342 was added to the cell culture medium to give final concentrations of $10 \mu \mathrm{g} / \mathrm{ml}$ and $1 \mu \mathrm{g} / \mathrm{ml}$ respectively and, after $5 \mathrm{~min}$ at $37^{\circ} \mathrm{C}$, cells were placed under a fluorescence microscope (Nikon Optiphot) with a filter block giving excitation at $380 \mathrm{~nm}$ and $480 \mathrm{~nm}$. Cells with disrupted membranes preferentially gave strong red nuclear fluorescence due to the uptake of PI. Cells with intact cell membranes gave blue nuclear fluorescence, due to the uptake of the cell permeable Hoechst 33342 fluorochrome.

\section{Determination of mitochondrial metabolism}

As mitochondria have been implicated in the initiation of the death process, an estimate of mitochondrial metabolism was made by the addition of the diazo dye, 3-[4,5dimethylthiazol-2-z-yl]-2,5-diphenyltetrazolium bromide (MTT), a compound that is metabolised at an early point in the electron transport chain (Slater et al. 1963) to give a blue insoluble formazan crystals. Except where stated, MTT dissolved in PBS was added to cells for $4 \mathrm{~h}$ to give a final concentration of $0 \cdot 1 \mathrm{mg} / \mathrm{ml}$. The blue crystals were solubilized by the addition of SDS in $\mathrm{HCl}$ to give final concentrations of $10 \%$ and $10 \mathrm{mM}$, respectively. Absorbance values were determined at $550 \mathrm{nM}$. This method is often used to give an estimate of viable cell numbers, as we have indicated in a previous study (Newton 1995). Due to the fact that experimental treatment periods were relatively short (24 to $48 \mathrm{~h}$ ), with the exception of data presented in Fig. 2, results presented here reflect differences in metabolic activity, as opposed to gross differences in cell numbers.

\section{Determination of cell death by DNA fragmentation}

Previous work (Newton 1995) has suggested that ZM 182780-induced death of $\mathrm{GH}_{3}$ cells has more of the 
characteristics of apoptosis than of necrosis (Schwartzman \& Cidlowski 1993). Indeed, in our previous study we have shown that antioestrogen exposure provokes cytosolic and nuclear shrinkage together with DNA fragmentation as detected by TUNEL assays (TdT-mediated dUTP nick and labelling). To quantitate cell death in the current study, we have used an ELISA that measures DNA fragmentation. According to the manufacturer of the ELISA $^{\text {PLUS }}$ (Boehringer Mannheim), the assay is optimised to measure DNA fragmentation that occurs during apoptosis as opposed to that which occurs during necrosis. To provide some degree of independent validation of the ELISA, we have used an endothelial cell line, EA.hy 926 (Claise et al. 1997), that responds to low doses of hydrogen peroxide $\left(\mathrm{H}_{2} \mathrm{O}_{2}\right)$ by undergoing classical apoptosis, as shown in Fig. $1 \mathrm{~b}$, and to higher doses of $\mathrm{H}_{2} \mathrm{O}_{2}$, by undergoing classical necrosis (Fig. 1c). Over a dose range of 300 to $900 \mu \mathrm{M} \mathrm{H}_{2} \mathrm{O}_{2}$, Fig. 1d shows that the amount of DNA fragmentation detected increases to reach a maximum over the range 500 to $700 \mu \mathrm{M}$ and falls to that of the control, untreated cells at $900 \mu \mathrm{M}$ where, as shown in (c), classical necrosis occurs. Accompanying the signs of necrosis, Fig. 1d also shows that the cytosolic enzyme, lactate dehydrogenase, measured according to the instructions provided by the manufacturer of the assay kit, Boehringer Mannheim, is released into the cell culture media, indicating the loss of cytosolic membrane integrity. The ELISA $^{\text {PLUS }}$ assay is therefore specific for DNA breakdown that occurs during classical apoptosis and fails to detect DNA fragmentation in classical necrosis.

Flow cytometry for intracellular peroxides and changes in $\Delta \Psi_{m}$

To test for the production of intracellular ROS in response to antioestrogen treatment, $\mathrm{GH}_{3}$ cells were removed from $75 \mathrm{~cm}^{2}$ culture flasks and resuspended in culture medium containing $10 \mu \mathrm{M}$ dichlorodihydrofluorescein diacetate $\left(\mathrm{H}_{2} \mathrm{DCF}\right)$. In the presence of intracellular peroxides, this ester is cleaved to yield a fluorescent product (Behl et al. 1997a). Following a $30 \mathrm{~min}$ exposure to $\mathrm{H}_{2} \mathrm{DCF}$, cells were sampled by a Beckton Dickinson FACS Calibur flow cytometer with an argon laser tuned to $480 \mathrm{nM}$ and detection in the green fluorescence, FLT-1 channel (x-axis).

Mitochondrial membrane potential $\left(\Delta \Psi_{\mathrm{m}}\right)$ was determined by a previously published method (Decaudin et al. 1997). $\mathrm{GH}_{3}$ cells pre-treated with $\mathrm{ZM} 182780$ for $24 \mathrm{~h}$ were harvested from $75 \mathrm{~cm}^{2}$ flasks by the addition of trypsin/EDTA and treated in suspension with $100 \mu \mathrm{M}$ $\mathrm{H}_{2} \mathrm{O}_{2}$. After $1 \mathrm{~h}$ and thereafter at approximately $30 \mathrm{~min}$ intervals, $300 \mu \mathrm{l}$ of cell suspension was taken to which was added $30 \mu \mathrm{l}$ of PBS containing the cationic dye, $\mathrm{DiOC}_{6}$ (final concentration $80 \mu \mathrm{M})$ and PI $(1 \mu \mathrm{g} / \mathrm{ml})$. Labelled cells were then incubated for $10 \mathrm{~min}$ at $37^{\circ} \mathrm{C}$ prior to sampling by the FACS ${ }^{\text {Calibur }}$ using the same parameters as for the above assay. Loss of $\Delta \Psi_{\mathrm{m}}$ was detected as a decrease in fluorescence intensity ( $\mathrm{x}$-axis of figures).

\section{Transfection}

$\mathrm{GH}_{3}$ cells were transfected with the Bcl-2 expression vector, RcCMV-Bcl-2 (Grimm et al. 1996). Following transfection of adherant cells in $25 \mathrm{~cm}^{2}$ culture flasks with $1 \mu \mathrm{g}$ of the plasmid construct, using the protocol described for the FUGENE transfection reagent (Boehringer Mannheim), cells were left undisturbed for $18 \mathrm{~h}$. These were then scraped from the culture surface and resuspended in $3 \mathrm{ml}$ of tissue culture medium to which was added $\mathrm{H}_{2} \mathrm{O}_{2}$, as descibed above for the flow cytometry studies with $\mathrm{DiOC}_{6}$.

\section{Statistics}

The statistical analysis presented here was performed on a minimum of 3 replicates using Student's $t$-test. All values presented in the figures are expressed as mean \pm S.D.

\section{Results}

Characteristics of ZM 182780-induced cell death and response to antioxidant, $N A C$

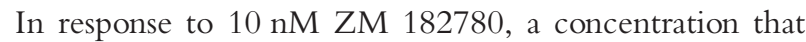
we have previously shown to induce the complete functional inactivation of the ER (Newton et al. 1994a), pituitary $\mathrm{GH}_{3}$ cells show signs of cell death 3 to 6 days after first treatment. For measurements made after the addition of MTT to cells on each day of a 6 day treatment period, Fig. 2a shows that the number of metabolically viable cells began to fall after 3 days treatment with $10 \mathrm{nM} \mathrm{ZM}$ 182780 and, as indicated in Fig. 2b, there was a parallel increase in DNA fragmentation. As indicated on this figure, the fall in metabolic activity with time and the increase in DNA fragmentation, were completely blocked by the inclusion of an excess of oestradiol in the culture medium. Indeed, although not shown, for all the following studies the effect of ZM 182780 was completely reversed by a 10 -fold excess of oestradiol. As indicated in a previous study (Newton et al. 1995), cells with low metabolic activity demonstrated marked cytoplasmic and nuclear shrinkage (3- to 5 -fold versus control cells), but they failed to exclude PI, as determined by fluorescence microscopy. Indeed for 5 similar experiments, where cells were treated with ZM 182780, fluorescence microscopy revealed that between 29 and $78 \%$ of the cell population had taken up PI. These observations are consistent with neither classical apoptosis nor necrosis (Schwartzman \& Cidlowski 1993). In our experience of a number of cell models, including the endothelial cells shown in Fig. 1, classical necrosis is characterised by little change in cell and nuclear volume, 

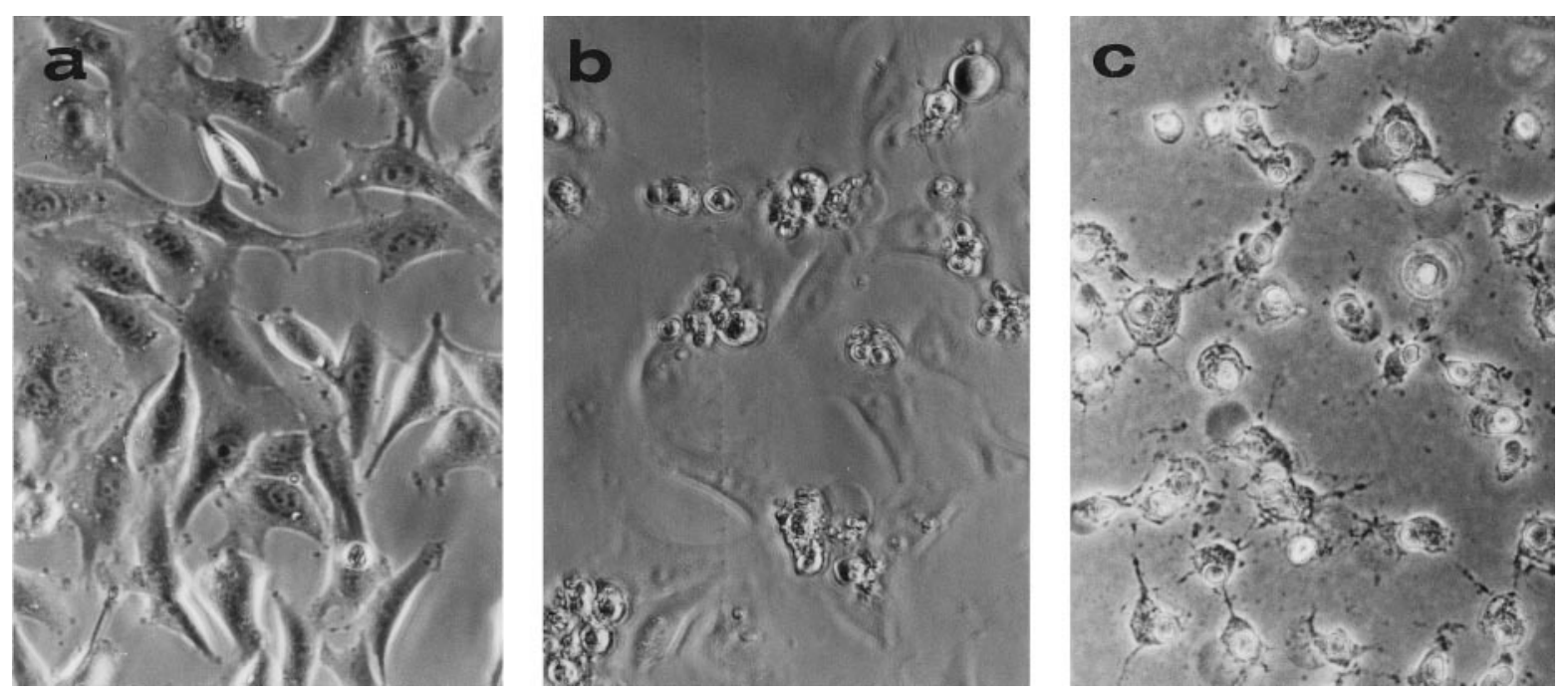

(d)

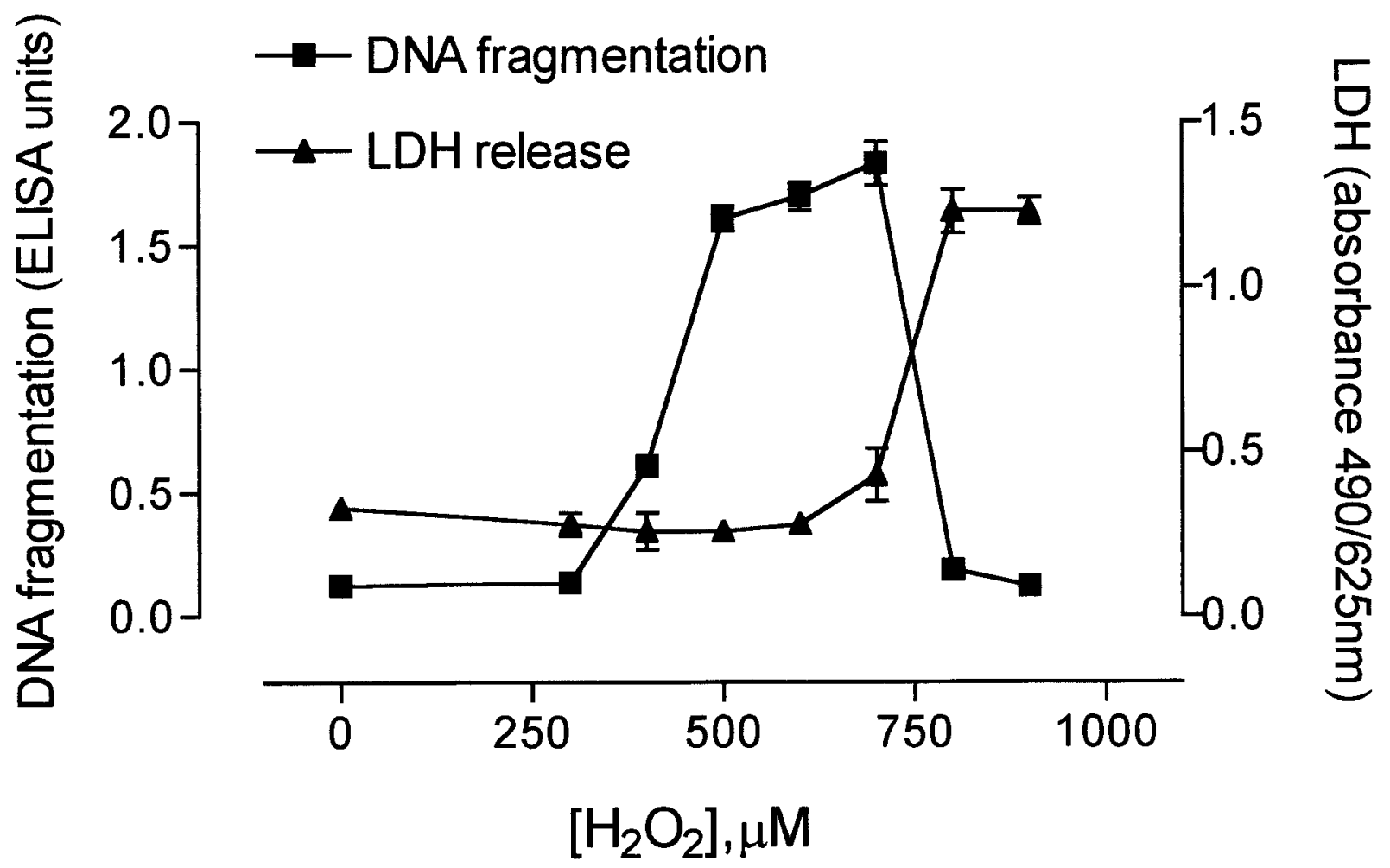

Figure 1 Normal light microscope appearance of endothelial EA.hy 926 cells treated with $500 \mu \mathrm{M} \mathrm{H}_{2} \mathrm{O}_{2}$ (b) and $800 \mu \mathrm{M}$ (c) in comparison to control untreated cells (a). The graphic (d) of this Figure shows DNA fragmentation measured with an ELISA and in parallel, the release of lactate dehydrogenase into the culture medium $24 \mathrm{~h}$ after the addition of $\mathrm{H}_{2} \mathrm{O}_{2}$. For this and subsequent Figures, values are mean \pm S.D. for at least 3 replicates. 
(a)

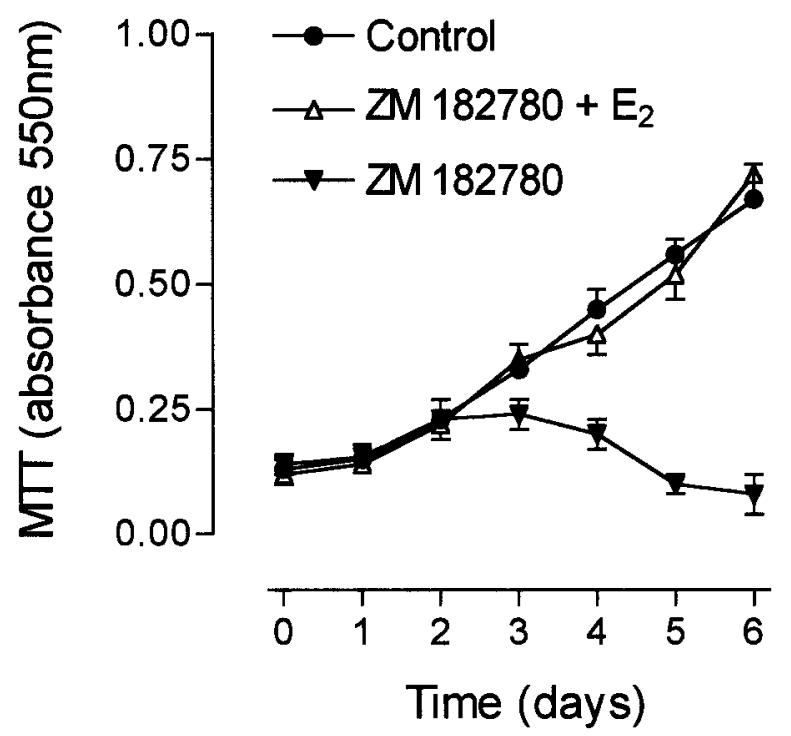

(b)

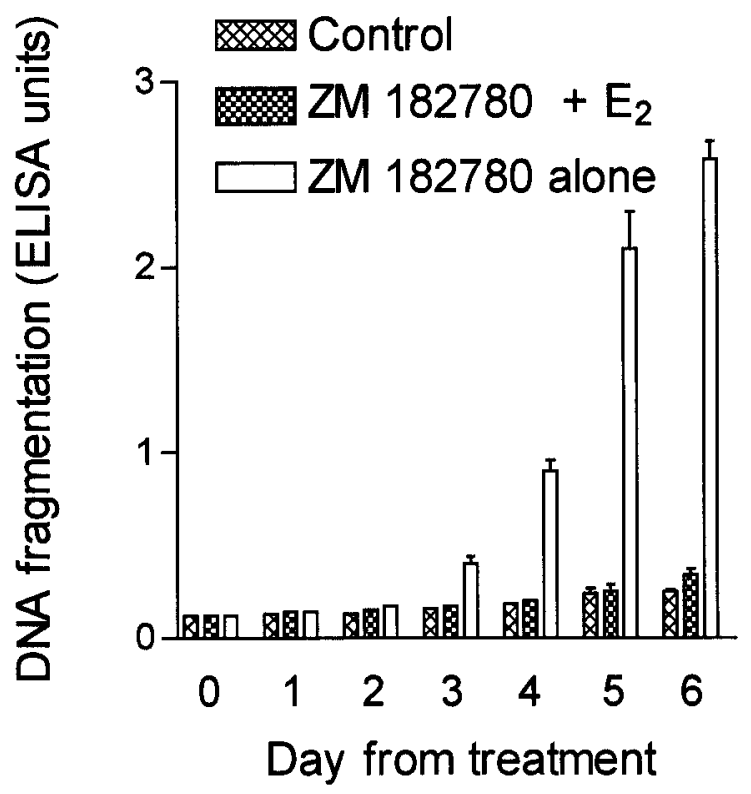

Figure 2 The response of $\mathrm{GH}_{3}$ cells to ZM $182780(10 \mathrm{nM})$ alone and ZM in combination with oestradiol (100 nM) over a time course of 6 days. In (a) viable cell numbers are quantitated by the addition of MTT and in (b) DNA fragmentation is measured by ELISA.

or an increase in both. For all the cell types demonstrating the necrotic morphology defined above, DNA fragmentation was not detected by the DNA fragmentation ELISA or following agarose gel electrophoresis of isolated cellular DNA (data not shown). Based on these observations, it is likely that our difficulty in characterising death of $\mathrm{GH}_{3}$ cells induced by ZM 182780 is due to the fact necrosis intervenes before the full apoptotic programme can be completed. This idea will be addressed again later in this report.

To determine whether intracellular oxidants played a role in ZM 182780-induced $\mathrm{GH}_{3}$ cell death, the experimental studies as indicated above were repeated in the presence of the thiol antioxidant and glutathione precursor, $\mathrm{N}$-acetyl cysteine (NAC) (Johnson et al. 1996). For measurements of DNA fragmentation made with the ELISA $^{\text {PLUS }}$ assay, Fig. 3 shows that in the absence of other additions, ZM 182780 resulted in a significant increase in DNA breakdown from day 3 onwards. In the presence of $250 \mu \mathrm{M}$ NAC, this increase was completely blocked.

The effect of $Z M 182780$ on antioxidant defences, and on response to pharmacological modulation of ROS concentrations

The above study strongly indicated that ROS were involved in the cell death response of $\mathrm{GH}_{3}$ cells to ZM 182780. As ROS are always present within cells, even under apparently anaerobic conditions (Esposti \& McLennan 1998) we determined whether antioxidant defences were depressed by antioestrogen exposure. Experiments were performed where intracellular oxidant formation was measured by incubation of ZM 182780 pretreated cells with $\mathrm{H}_{2} \mathrm{DCF}$, followed by flow cytometry as described in Methods. Figure 4 shows there is no marked difference in the fluorescence intensity profiles after $48 \mathrm{~h} \mathrm{ZM} 182780$ exposure. Over 5 experiments, the $22 \pm 7 \%$ of cells showing an increase in peroxide-induced $\mathrm{H}_{2} \mathrm{DCF}$ cleavage was not significantly different from control untreated cells, $25 \pm 8 \%$. After a further $24 \mathrm{~h}$ exposure, the fluorescence profile of Fig. 4 shows a shift to higher intensities, indicating an increase in intracellular oxidant concentrations ( $45 \pm 9 \%$ vs control, $19 \pm 7 \%$, $P<0 \cdot 01)$.

Further experiments to address the effects of intracellular oxidant generation were performed using the compound L-buthionine-[S,R]-sulphoxamine (BSO), an agent that blocks the endogenous synthesis of the glutathione peroxidase cofactor, glutathione (Griffith 1979), leading to hightened intracellular $\mathrm{H}_{2} \mathrm{O}_{2}$ exposure. Experiments were performed on cells under normal in vitro cell culture conditions containing $21 \% \mathrm{O}_{2}$ and under the relative hypoxic condition of $5 \% \mathrm{O}_{2}$. Cells treated with $\mathrm{ZM}$ 182780 for $24 \mathrm{~h}$ were then exposed to BSO over the concentration range $50 \mu \mathrm{M}$ to $300 \mu \mathrm{M}$. Figure 5 a shows that, at the end of a $24 \mathrm{~h}$ period of exposure to BSO alone, DNA breakdown could not be detected, despite the increase in intracellular oxidants, as indicated by the insert, for measurements made by flow cytometry with $\mathrm{H}_{2} \mathrm{DCF}$. 


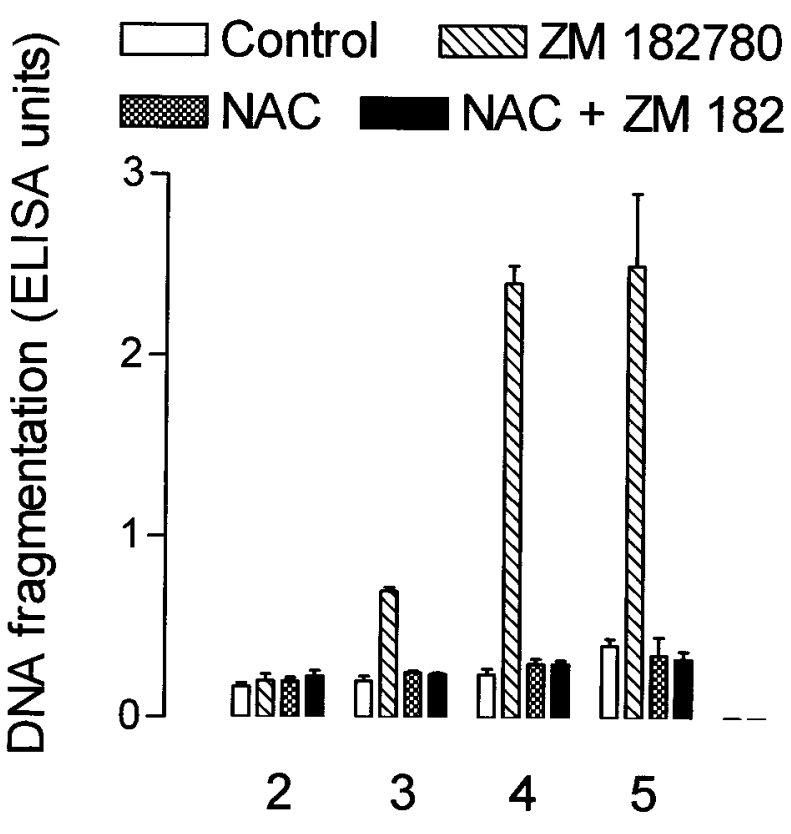

\section{Day from treatment}

Figure 3 DNA fragmentation within $\mathrm{GH}_{3}$ cells in response to ZM $182780(10 \mathrm{~nm})$ over a 5 day period in the absence and presence of the antioxidant, NAC $(500 \mu \mathrm{M})$.

In contrast, cells pre-treated with ZM 182780 for $24 \mathrm{~h}$ under 'normoxic' conditions showed significant DNA fragmentation after $24 \mathrm{~h}$ exposure to $\mathrm{BSO}$ at concentrations from $25 \mu \mathrm{M}$ and higher. This was completely blocked by the antioxidant, NAC, confirming that cell death was due to ROS accumulation. In parallel with the DNA fragmentation detected by ELISA, there was a large decrease in metabolic activity (Fig. 5b). Under the relative hypoxic condition of $5 \% \mathrm{O}_{2}$, no marked $\mathrm{BSO}$-induced DNA fragmentation could be observed for the ZM 182780 pre-treated cells (data not shown) and metabolic activity was not affected by BSO as shown in Fig. 5c. These results strongly suggest that loss of ER function sensitises cells to $\mathrm{H}_{2} \mathrm{O}_{2}$ accumulation due to the inadequacy of the glutathione peroxidase reaction (Halliwell \& Gutteridge 1990). Clearly, reducing the environmental oxygen concentrations blocks this effect.

\section{Response of cells to $\mathrm{H}_{2} \mathrm{O}_{2}$}

$\mathrm{H}_{2} \mathrm{O}_{2}$ freely diffuses across cell membranes and it has been used to induce oxidative stress in numerous previous studies (Schmidt et al. 1986, Meyer et al. 1993, Behl et al. 1997a). Preliminary experiments, where pituitary $\mathrm{GH}_{3}$ cells were exposed to $\mathrm{H}_{2} \mathrm{O}_{2}$ alone over the concentration range $50 \mu \mathrm{M}$ to $1 \mathrm{mM}$, revealed that cell morphology changed within $2 \mathrm{~h}$, at doses of peroxide over the range 50 to $400 \mu \mathrm{M}$, to that observed for the long-term antioestrogen treated cells. Paradoxically, at the high $\mathrm{H}_{2} \mathrm{O}_{2}$ doses $(1 \mathrm{mM})$, cell morphology remained relatively unaltered for the first 2 to $3 \mathrm{~h}$ with no evidence of DNA fragmentation. For one of these experiments, Fig. 6a shows that DNA fragmentation increased with time, at the higher $\mathrm{H}_{2} \mathrm{O}_{2}$ doses. Again, contrary to expectations, in contrast to the low doses, where cytosolic membrane integrity, as evident by PI uptake, was lost within $2 \mathrm{~h}$ of $\mathrm{H}_{2} \mathrm{O}_{2}$ treatment, for a large proportion of the cell population (range, 39-78\%, for 7 experiments), the swelling, high dose treated cells excluded PI for several hours. Finally, after around $8 \mathrm{~h}$ post $1 \mathrm{mM} \mathrm{H}_{2} \mathrm{O}_{2}$, all cells showed PI uptake as observed by fluorescence microscopy.

This experiment was repeated for cells pre-treated with ZM 182780 for $24 \mathrm{~h}$. Figure 6b shows these data for measurements made with the ELISA ${ }^{\text {PLUS }}$ assay, $2 \mathrm{~h}$ after the addition of $\mathrm{H}_{2} \mathrm{O}_{2}$. Antioestrogen pre-treatment clearly enhanced the ability of $\mathrm{H}_{2} \mathrm{O}_{2}$ at concentrations below $400 \mu \mathrm{M}$ to induce DNA fragmentation and, as shown in Fig. 6c, to induce loss of mitochondrial activity, determined by the addition of MTT. Paradoxically, mitochondrial activity was maintained at the higher peroxide doses in the absence of ZM 182780 and was maintained to a lesser extent in the presence of ZM 182780.

It is more usual for low doses of $\mathrm{H}_{2} \mathrm{O}_{2}$ to induce apoptosis and high doses to induce necrosis (see Fig. 1). The $\mathrm{GH}_{3}$ cell response to $\mathrm{H}_{2} \mathrm{O}_{2}$ is clearly unusual in that delayed DNA fragmentation is induced at the high doses whilst at the lower doses, cell death is observed within $2 \mathrm{~h}$. However, given that $\mathrm{H}_{2} \mathrm{O}_{2}$ doses less than $100 \mu \mathrm{M}$ are likely to be encountered under physiological conditions (Esposti \& McLennan 1998), the rapidity of the response to these lower doses, in comparison to death induced by ZM 182780 treatment alone (see Fig. 2), begs the question as to whether the same mechanism is being addressed. Experiments were therefore performed to determine whether low dose oxidant sensitivity was enhanced as a function of the time these cells were exposed to ZM 182780. Figure 6d shows that, at least for the $72 \mathrm{~h} \mathrm{ZM}$ 182780 pre-exposure, a significant increase in DNA fragmentation over and above the untreated control cells was now noted at $25 \mu \mathrm{M} \mathrm{H} \mathrm{H}_{2} \mathrm{O}_{2}$. This effect was not apparent for the cells pre-treated with the antioestrogen for 24 or $48 \mathrm{~h}$. These data would further substantiate the claim that ZM 182780 enhances sensitivity to oxidants, and provide the additional information that the degree of sensitisation is a function of antioestrogen exposure time.

\section{$\Delta \Psi_{m}$ disruption in response to $\mathrm{H}_{2} \mathrm{O}_{2}$ and $Z M 182780$ pre-treatment}

Our experiments have strongly suggested that loss of ER function enhances sensitivity of $\mathrm{GH}_{3}$ cell to ROS. Recent studies suggest that the cell death and, in particular, apoptotic cell death, is initiated by events that bring about 


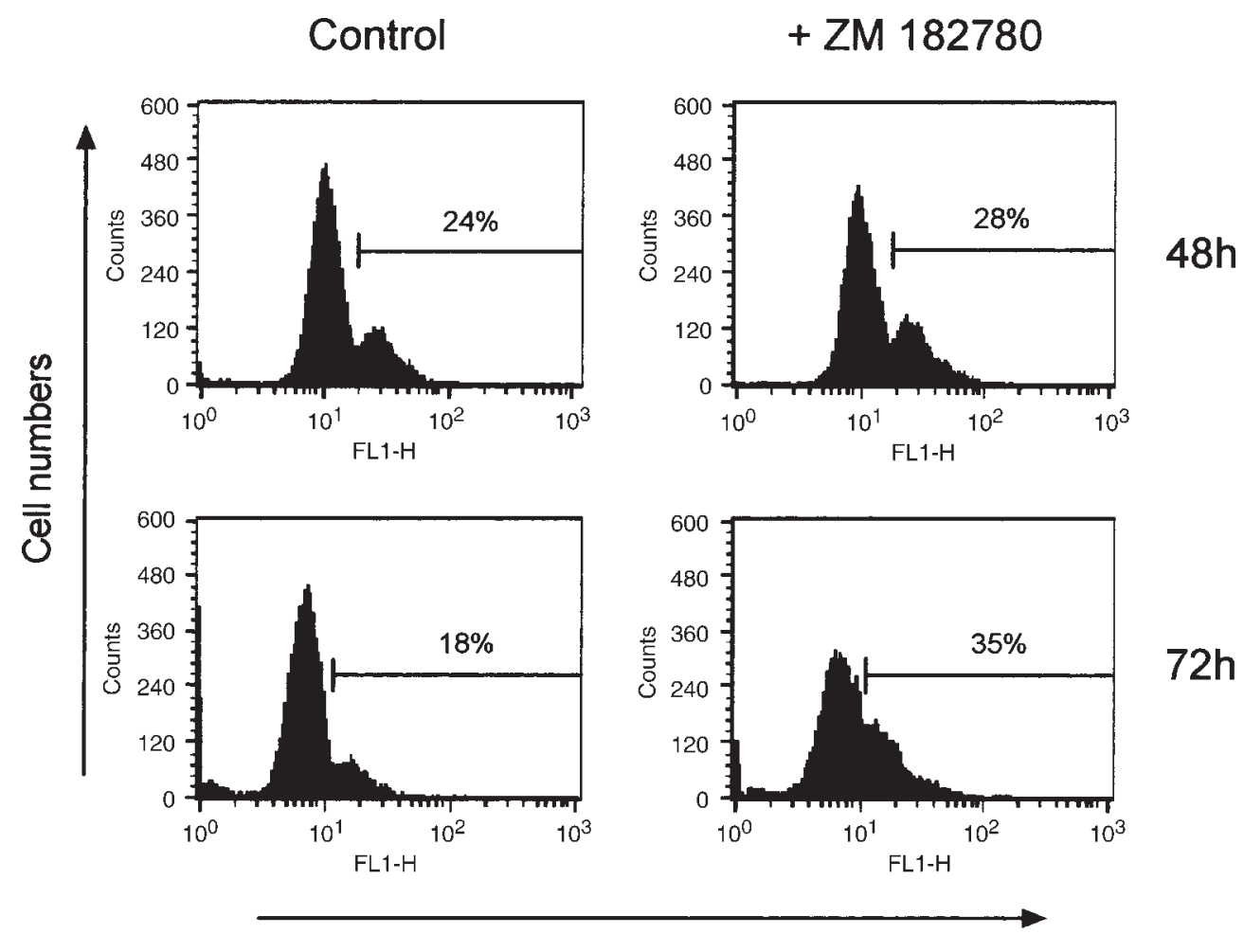

Fluorescence intensity (peroxide formation)

Figure 4 Accumulation of intracellular peroxides, measured by the addition of $\mathrm{H}_{2} \mathrm{DCF}$, following $48 \mathrm{~h}$ or $72 \mathrm{~h}$ treatment with ZM $182780(10 \mathrm{nM})$. The area to the right of the bar indicates the percentage of the cell population showing an increased intracellular peroxide concentration.

the loss of mitochondrial membrane potential $\left(\Delta \Psi_{\mathrm{m}}\right)$. The $\Delta \Psi_{\mathrm{m}}$ is generated by active oxidative phosphorylation, where the electron flow through the inner mitochondrial membrane is used to pump protons out of the intramitochondrial space. The resulting electrochemical gradient drives ATP synthesis. Apoptotic and necrotic cell death is thought to be initiated when mitochondria undergo a permeability transition (Zoratti \& Szabò 1995). In the case of apoptosis, the loss of mitochondrial cytochrome c and as yet, uncharacterised apoptosis-inducing factors (AIFs) from the mitochondrial matrix, is thought to activate the caspase cascade (Yang et al. 1997, Zhivotovsky et al. 1998). For the current study, a direct assessment of the $\Delta \Psi_{\mathrm{m}}$ was made by labelling cells with the cationic dye $\mathrm{DiOC}_{6}$, as indicated in Methods. As a positively charged substance, $\mathrm{DiOC}_{6}$ accumulates within the inner membrane space as a function of the $\Delta \Psi_{\mathrm{m}}$ and emits green fluorescence, in proportion to its concentration. The graphic of Fig. 7 shows these data for $\mathrm{DiOC}_{6}$ fluorescence at two time points following $\mathrm{H}_{2} \mathrm{O}_{2}$ addition. For all time points tested, the associated table indicates the percentage of the cell population that have low $\Delta \Psi_{\mathrm{m}}$ and have taken up PI. From the figure it can be seen that little increase in the low intensity fluorescence corresponding to that induced by the mitochondrial uncoupling agent, carbonyl cyanide $m$-chlorophenylhydrazone (Fig. 7A, open profile corresponding to region M1 shown in I), was induced by short term pre-exposure $(24 \mathrm{~h})$ to $\mathrm{ZM} 182780$ alone. However, for these ZM 182780 pre-treated cells, the majority have lost $\Delta \Psi_{\mathrm{m}}$ in response to $\mathrm{H}_{2} \mathrm{O}_{2}$ treatment for $135 \mathrm{~min}$. The associated table shows that the effect of ZM 182780 on $\mathrm{H}_{2} \mathrm{O}_{2}$-induced loss of $\Delta \Psi_{\mathrm{m}}$ becomes statistically significant after $105 \mathrm{~min}$ of exposure. For the 135 min time point following $\mathrm{H}_{2} \mathrm{O}_{2}$ treatment, Fig. 7 also shows that over-expression of the mitochondrial protein, Bcl-2, partially prevents the ZM 182780 enhanced loss of $\Delta \Psi_{\mathrm{m}}$. Although not shown in Fig. 7, it must be pointed out that the effects of ZM 182780 were completely blocked by co-incubation with oestradiol at a concentration of $100 \mathrm{nM}$.

\section{Discussion}

These data presented in this paper have firmly established a role for $\mathrm{ROS}$ in the cytotoxic response of pituitary $\mathrm{GH}_{3}$ cells to the antioestrogen, ZM 182780. A major premise on which these studies were conducted was that ROS have been shown to have a role in several human diseases, 


\section{(a) DNA fragmentation $\left(21 \% \mathrm{O}_{2}\right)$}

(b) Metabolic activity $\left(21 \% \mathrm{O}_{2}\right)$
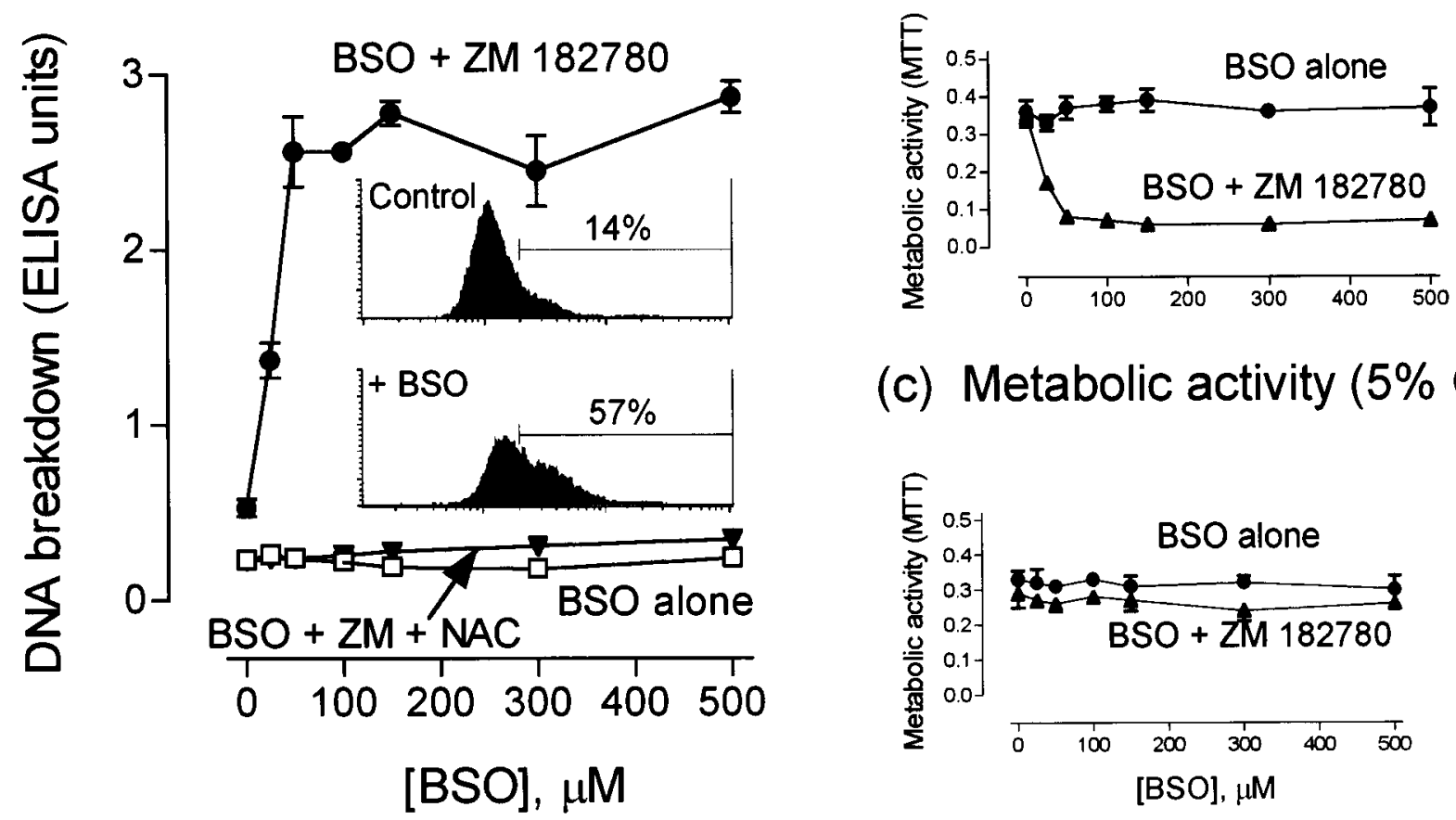

\section{(c) Metabolic activity $\left(5 \% \mathrm{O}_{2}\right)$}

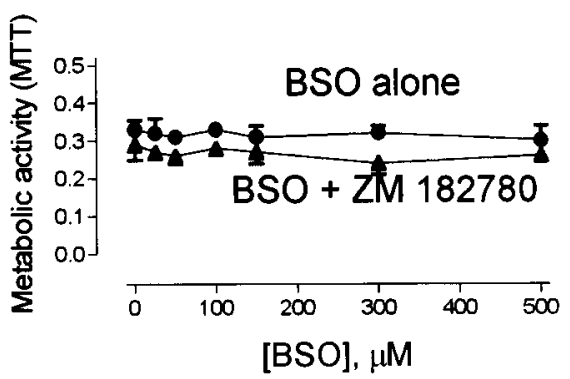

Figure 5 The effect of blocking glutathione synthesis with BSO in the absence and presence of $10 \mathrm{nM}$ ZM 182780 alone or with the antioxidant NAC, under normoxic ( $a$ and b) and relative hypoxic culture conditions (c). In (a), DNA fragmentation was measured by ELISA and in (b) and (c), metabolic activity was measured by the addition of MTT $24 \mathrm{~h}$ after BSO exposure. The inset in (a) shows the accumulation of $\mathrm{H}_{2} \mathrm{O}_{2}$ as measured by the addition of $\mathrm{H}_{2}$ DCF, $24 \mathrm{~h}$ after the addition of $300 \mu \mathrm{M}$ BSO alone. Although not shown, $\mathrm{H}_{2} \mathrm{O}_{2}$ accumulation could not be detected under the relative hypoxic condition of $5 \% \mathrm{O}_{2}$.

amongst which notable examples are Alzheimer's (Coyle \& Puttfarcken 1993) and atherosclerosis (Diaz et al. 1997). This was reinforced by our recent demonstration that ZM 182780 enhances sensitivity to gamma irradiation (Newton et al. 1998), a treatment modality known to induce ROS (Datta et al. 1992). ROS are formed within cells as a fundamental consequence of an aerobic environment. Amongst other sites for their production (Ramasara 1982), mitochondria are one of the prinicipal sites for $\mathrm{H}_{2} \mathrm{O}_{2}$ production (Boveris \& Chance 1973). Although $\mathrm{H}_{2} \mathrm{O}_{2}$ is relatively unreactive and cannot be described as a free radical, its synthesis can damage cellular structures due to the fact that, in the presence of transition metals, such as iron $\left(\mathrm{Fe}^{2+}\right)$, it is converted to the potent oxidizing agent, the $\mathrm{OH}$ radical.

Whilst our experiments with the antioxidant, NAC, have provided firm evidence that $\mathrm{GH}_{3}$ cell death induced by ZM 182780 involves oxidants, our studies with the compound $\mathrm{H}_{2} \mathrm{DCF}$ would suggest that intracellular oxidant concentrations are not altered by ZM 182780 . Although some increase is observed $72 \mathrm{~h}$ after antioestrogen treatment, by this stage, DNA fragmentation has increased. It is already known that the cellular changes occurring during apoptosis are associated with heightened ROS production (Kroemer et al. 1997), so our observation may reflect the outcome and not the initiating event of cell death. This infers that the enzymes, glutathione peroxidase and catalase, both of which are capable of disposing of $\mathrm{H}_{2} \mathrm{O}_{2}$ generated as a result of metabolic events (Akman et al. 1989), are not under the control of the ER response pathway. Based on this, and our studies with NAC, a likely explanation for the effects of ZM 182780 exposure is that ROS trigger cell death, when the threshold for initiating such a response is lowered by loss of ER function. This idea finds support from studies presented in Figs 5 and 6 where the effect of endogenous manipulation of oxidant levels with $\mathrm{BSO}$ and exogenous administration of $\mathrm{H}_{2} \mathrm{O}_{2}$ are explored. Here it is shown that ZM 182780 exposure markedly sensitises cells to elevated ROS concentrations. The experiments presented in Fig. 5 clearly show that the outcome of manipulating glutathione concentrations by the glutathione synthase inhibitor, $\mathrm{BSO}$, is absolutely dependent on the ambient $\mathrm{O}_{2}$ concentrations. Under relative hypoxia, ZM 182780 fails to facilitate death due to glutathione depletion, strongly suggesting that cellular oxidant formation is depressed. 
(a)

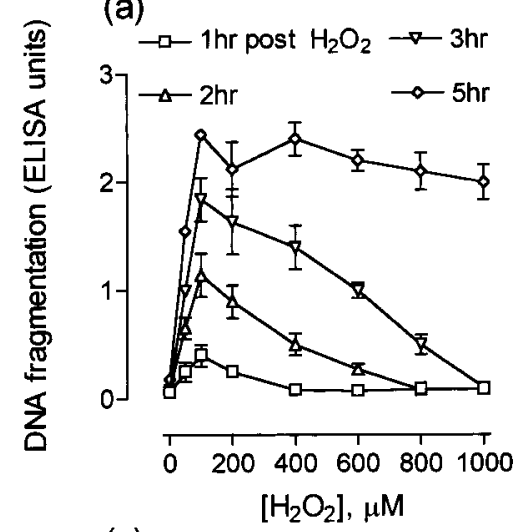

(c)

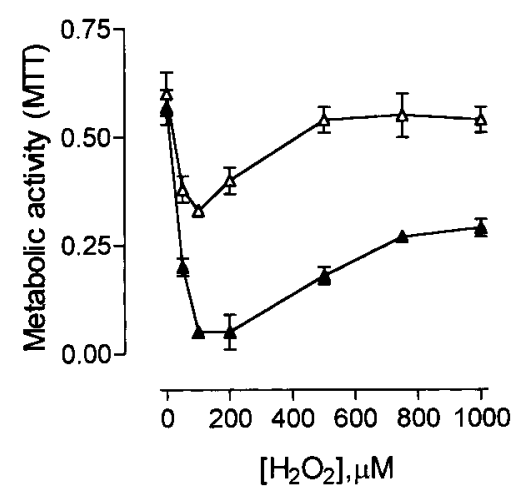

(b)

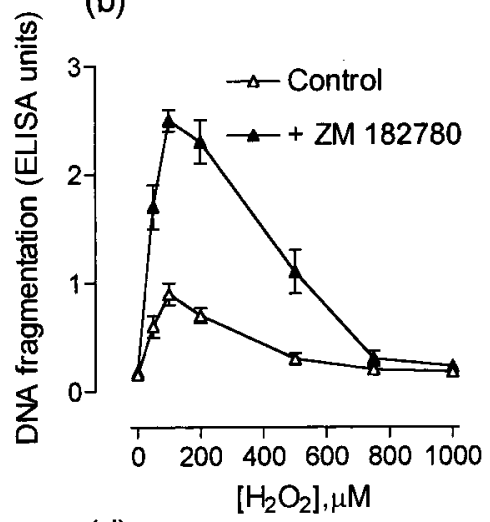

(d)

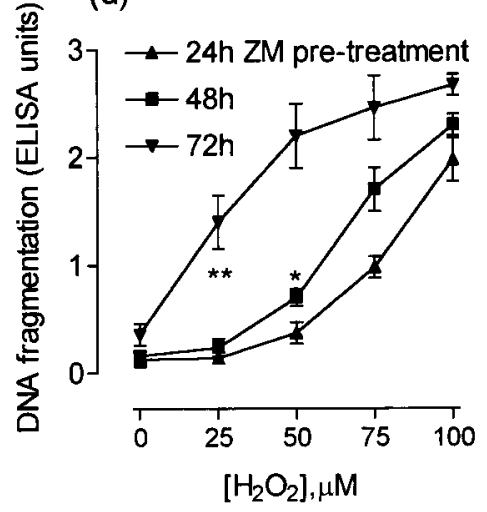

Figure 6 The effect of a concentration range of $\mathrm{H}_{2} \mathrm{O}_{2}$ on DNA fragmentation and metabolic activity within $\mathrm{GH}_{3}$. In (a) the time course for DNA fragmentation is presented; for a separate study, (b) displays the effect of a $2 \mathrm{~h}$ exposure to $\mathrm{H}_{2} \mathrm{O}_{2}$ on untreated cells and cells pre-incubated with $10 \mathrm{nM}$ ZM $182780(24 \mathrm{~h})$ measured as DNA fragmentation and metabolic activity after the addition of MTT (c). In (d), an experiment is shown where the effect of duration of antioestrogen exposure on DNA fragmentation in response to low $\mathrm{H}_{2} \mathrm{O}_{2}$ concentrations, is tested. vs no addition of $\mathrm{H}_{2} \mathrm{O}_{2}:{ }^{*} P<0 \cdot 01,{ }^{* *} P<0 \cdot 001$.

Given that oxidants appear to be involved in the survival/death equation of these $\mathrm{GH}_{3}$ cells and other cell types (Behl et al. 1997b), it may be no accident of nature that, as a source of ROS, mitochondria are becoming firm candidates as the main integration site for events that lead to apoptosis and necrosis (Zamzami et al. 1997). Mitochondria in their normal oxidative capacity generate a transmembrane potential that allows the generation of ATP. This transmembrane potential $\left(\Delta \Psi_{\mathrm{m}}\right)$ can collapse by the opening of permeability transition (PT) pores within the inner mitochondrial membrane (Zoratti \& Szabò 1995), thus allowing mitochondria to release low molecular weight proteins and cytochrome $\mathrm{c}$ that together activate the cascade of the apoptotic pathway (Kluck et al. 1997, Petit et al. 1996). PT is sensitive to many factors, prominent amongst which are ROS, and mitochondrial electron transport chain disruptors (Zoratti \& Szabò 1995, Reed 1997). It is currently thought that PT is regulated by a complex of proteins including the apoptosis regulator, Bcl-2 (Zamzami et al. 1997, Reed 1997). Studies by other groups have suggested that Bcl-2 is regulated by oestrogens (Wang \& Phang 1995). Our observations on the ability of ZM 182780 to enhance the ability of $\mathrm{H}_{2} \mathrm{O}_{2}$ to collapse $\Delta \Psi_{\mathrm{m}}$ and the ability of Bcl-2 over-expression to partially block this response are consistent with this, but do not exclude the possibility that the ER directly controls the expression of components of the electron transport chain. Indeed, only relatively recently was it appreciated that the transmembrane potential held the PT pore from opening and that loss of $\Delta \Psi_{\mathrm{m}}$ could be the cause as well as the consequence of PT (Petronilli et al. 1993). In support of this, for a related cell line, $\mathrm{GH}_{4} \mathrm{C}_{1}$, others have indicated that oestrogens alter the concentration of mitochondrially encoded cytochrome c oxidase subunit II (VanItallie \& Dannies 1988). Evidence also exists for the presence of DNA binding sites in the mitochondrial genome for other members of the steroid receptor superfamily (Demonacos et al. 1995). Therefore, the ER might directly control mitochondrial energy flux, thereby influencing the ability of ROS to induce PT and, as a consequence, cell death. 


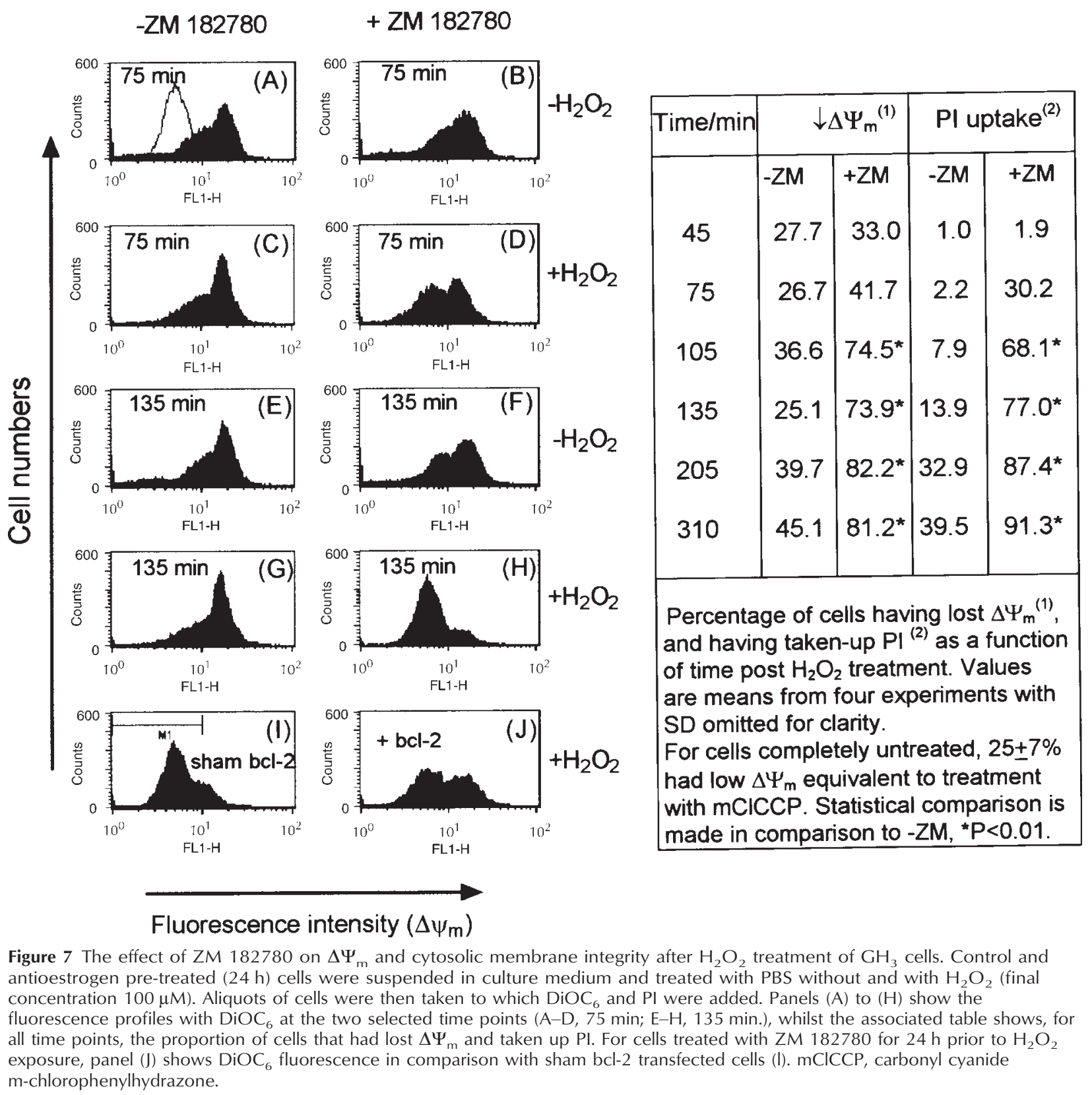

Before a final comment as to the significance of our findings, this discussion would be incomplete without referring to the anomalous nature of $\mathrm{GH}_{3}$ cell death induced by ZM 182780 alone and in combination with elevated oxidant exposure. Firstly, it is not possible to clearly define the mode of cell death in response to ZM 182780 or oxidants. Cell morphology is not consistent with either apoptosis alone or necrosis alone. There is a large reduction in cell and nuclear volume with corresponding DNA fragmentation; however, this is accompanied by low mitochondrial metabolic activity and loss of cell membrane integrity. We can only propose that part of the apoptotic programme is initiated, leading to endonuclease activation, and that this is rapidy overwhelmed by a progressive loss in overall cellular energy state and an inability to maintain membrane integrity. This cell line may provide an example of what has been termed 'necrosis supervened over apoptosis' (Raffray \& Cohen 1997). A second anomaly is the dose response to $\mathrm{H}_{2} \mathrm{O}_{2}$. It is generally considered that low doses of oxidants induce apoptosis and higher doses, necrosis. Indeed, this is our experience with the endothelial cells described in 
Methods and also for cancer and other cell lines (CJ Newton, unpublished observation). Figure $6 \mathrm{c}$ clearly shows that metabolic activity is maintained at the high peroxide doses in the absence of ZM 182780, an effect that is blunted by the presence of ZM 182780. These observations suggest that the high peroxide doses trigger a strong protective mechanism such that mitochondrial activity is maintained for several hours. If one is to make this proposal, then one must also propose that at the lower oxidant doses, the cells are unable to mount a sufficient 'stress reponse' to prevent the collapse of mitochondrial function and cell death. Although not shown here, we have evidence that metabolic activity in the presence of $1 \mathrm{mM} \mathrm{H}_{2} \mathrm{O}_{2}$ is maintained for greater than $90 \%$ of the cell population for at least $12 \mathrm{~h}$, by the inclusion of inhibitors of the enzyme poly (ADP-ribose) polymerase (PARP). During this period, DNA fragmentation was also prevented by these PARP inhibitors (CJ Newton, unpublished observations). PARP is an enzyme that is highly activated following DNA damage and results in a large fall of cellular ATP concentrations (Sims et al. 1983). These observations strongly suggest that it is the fall in the cellular energy state induced by the oxidant exposure, and not oxidant exposure per se, that is responsible for cell death.

Finally, our observation that oxidant sensitivity of this pituitary tumour cell line is increased by antioestrogen exposure should be considered in the light of therapeutic strategies where it is known that ROS are involved. As we have suggested earlier, our observations might provide the explanation for our recent findings that ZM 182780 increased the sensitivity of breast tumour cells to gamma radiation exposure (Newton et al. 1998). The current work also raises the question as to whether pure antioestrogens enhance the effect of ROS generating agents in other ER containing tumour cell types, such as the breast. From the experiments reported here on the role of ambient oxygen concentrations, it is quite likely that an in vivo role for oxidants in antioestrogen-induced cell death would depend on tissue oxygen saturation. For this reason it will be important to determine the effect that antioestrogens have on the growth and survival of ER containing cells maintained under different ambient oxygen concentrations.

\section{Acknowledgements}

The authors wish to acknowledge the support given by Yorkshire Cancer Research and the GKS GmbH, Munich Germany, at the various stages of this study.

\section{References}

Akman SV, Forrest G, Chu FF \& Doroshow JH 1989 Resistance to hydrogen peroxide associated with altered catalase mRNA stability in MCF7 breast cancer cells. Biochemica et Biophysica Acta 1009 $70-74$.
Beckman JM, Allan GF, Tsai SY, Tsai MJ \& O’Malley BW 1993 Transcriptional activation by the estrogen receptor requires a conformational change in the ligand binding domain. Molecular Endocrinology 7 1266-1274.

Behl C, Lezoualc'h F, Trapp T, Widmann M, Skutella T \& Holsboer F 1997a Glucocorticoids enhance oxidative stress-induced cell death in hippocampal neurones in vitro. Endocrinology 138 101-106.

Behl C, Skutella T, Lezoualc'h F, Post A, Widmann M, Newton CJ \& Holsboer F $1997 b$ Neuroprotection against oxidative stress by estrogens: structure-activity relationship. Molecular Pharmachology 51 535-541.

Boveris A \& Chance B 1973 The mitochondrial generation of hydrogen peroxide. General properties and effect of hyperbaric oxygen. Biochemical Journal 134 707-716.

Claise C, Edeas CM, Abella A, Khalfoun Y, Laurent D \& Lindenbaum A 1997 Comparison of oxidized low-density lipoprotein toxicity on EA.hy 926 cells and human vein endothelial cells: influence of antioxidant systems. Cellular and Molecular Life Sciences 53 156-161.

Coyle JP \& Puttfarcken P 1993 Oxidatrive stress, glutamate, and neurodegenerative disorders. Science 262 689-695.

Datta R, Hallahan DE, Kharbanda SM, Rubin E, Sherman ML, Huberman E, Weichselbaum RR \& Kufe DW 1992 Involvement of reactive oxygen intermediates in the induction of c-jun gene transcription by ionizing radiation. Biochemistry 31 8300-8306.

Decaudin D, Geley S, Hirsch T, Castedo M, Marchetti P, Macho A, Kofler R \& Kroemer G 1997 Bcl-2 and Bcl-XL antagonize mitochondrial dysfunction preceding nuclear apoptosis induced by chemotherapeutic agents. Cancer Research 57 62-67.

Decensi A, Fontana V, Bruno S, Gustavino C, Gatteschi B \& Costa A 1996 Effect of tamoxifen on endometrial proliferation. Journal of Clinical Oncology 14 434-440.

Demonacos C, Djordjevic-Markovic R, Tsawdaroglou N \& Sekeris CE 1995 The mitochondrion as a primary site of action of glucocorticoids: the interaction of the glucocorticoid receptor with mitochondrial DNA sequences showing partial similarity to the nuclear glucocorticoid response elements. Journal of Steroid Biochemistry and Molecular Biology 55 43-55.

Diaz MN, Frei B, Vita JA \& Keaney JF 1997 Antioxidants and atherosclerotic heart disease. New England Journal of Medicine 337 408-416.

Esposti MD \& McLennan H 1998 Mitochondria and cells produce reactive oxygen species in virtual anaerobis: relevance to ceramideinduced apoptosis. FEBS Letters 430 338-342.

Gibson MK, Nemmers LA, Beckman WC, Davis VL, Curtis SW \& Korach KS 1991 The mechanism of ICI 164,384 antiestrogenicity involves rapid loss of estrogen receptor in uterine tissue. Endocrinology 129 2000-2010.

Griffith OW 1979 Potent and specific inhibition of glutathione synthesis by buthionine sulfoximine ( $\mathrm{S}$ - $n$-butyl homocysteine sulfoximine). Journal of Biological Chemistry 254 7558-7560.

Grimm S, Bauer MKA, Baeuerle PA \& Schulze-Osthoff K 1996 $\mathrm{Bcl}-2$ down-regulates the activity of transcription factor NF- $\mathrm{KB}$ induced upon apoptosis. Journal of Cell Biology 134 13-23.

Halliwell B \& Gutteridge JMC 1990 The role of free radicals and catalytic metal ions in human disease: an overview. Methods in Enzymology 186 1-85.

Howell A 1997 Antiestrogens: future prospects. Oncology 11 59-64.

Johnson TM, Yu ZX, Ferrans VJ, Lowenstein RA \& Finkel T 1996 Reactive oxygen species are downstream mediators of p53dependent apoptosis. Proceedings of the National Academy of Sciences of the USA 93 11848-11852.

Katzenellenbogen BS, Bhakoo HS, Ferguson ER, Lan NC, Tatee T, Tsai TL \& Katzenellenbogen JA 1979 Estrogen and antiestrogen action in reproductive tissues and tumours. Recent Progress in Hormone Research 35 259-300. 
Kluck RM, Bossy-Wetzel E, Green DR \& Newmeyer DD 1997 The release of cytochrome c from mitochondria: a primary site for Bcl-2 regulation of apoptosis. Science 275 1132-1136.

Kroemer G, Zamzami N \& Susin SA 1997 Mitochondrial control of apoptosis. Immunology Today 18 44-51.

Kuiper GGJM \& Gustafsson JA 1997 The novel estrogen receptor- $\beta$ subtype: potential role in the cell-and promotor-specific actions of estrogens and anti-estrogens. FEBS Letters 410 87-90.

McDonnell DP, Lieberman BA \& Norris J 1995 Development of tissue-selective estrogen receptor modulators. In Organ-selective actions of steroid hormones. Ed OT Baird, G Schutz \& R Krattenmacher. Germany: Springer-Verlag.

Meyer M, Schreck R \& Baeuerle PA $1993 \mathrm{H}_{2} \mathrm{O}_{2}$ and antioxidants have opposite effects on activation of NF- $\mathrm{KB}$ and $\mathrm{AP}-1$ in intact cells: AP-1 as secondary antioxidant-responsive factor. $E M B O$ Journal 12 2005-2015.

Newton CJ 1995 Estrogen receptor blockade by the pure antiestrogen, ZM 182780, induces death of pituitary tumour cells. Journal of Steroid Biochemistry and Molecular Biology 55 327-336.

Newton CJ, Trapp T, Pagotto U, Renner U, Buric R \& Stalla GK $1994 a$ The oestrogen receptor modulates growth of pituitary tumour cells in the absence of oestrogen. Journal of Molecular Endocrinology 12 303-312.

Newton CJ, Buric R, Trapp T, Brockmeier S, Pagotto U \& Stalla GK $1994 b$ The unliganded estrogen receptor (ER) transduces growth factor signals. Journal of Steroid Biochemistry and Molecular Biology 48 481-486.

Newton CJ, Arzt E \& Stalla GK 1994c Involvement of the estrogen receptor in the growth response of pituitary tumour cells to interleukin-2. Biochemical and Biophysical Research Communications 205 1930-1937.

Newton CJ, Koller G, Renner U, Pagotto U, Oertel H \& Stalla GK 1996 Pure antiestrogens synergise with dopamine agonists to block prolactin synthesis - a potential new therapeutic strategy for the treatment of prolactinomas, pp 313-317. In $6^{\text {th }}$ European Workshop on Pituitary Adenomas. Ed K von Werder. Excerpta Medica International Congress Series. Amsterdam: Elsevier.

Newton CJ, Schlatterer K, Stalla GK, von Angerer E \& Wowra B 1998 Pharmacological enhancement of radiosurgery response: studies on an in vitro model system. Journal of Radiosurgery 151-56.

Nowakowski BE \& Maurer RA 1994 Multiple pit-1 binding sites facilitate estrogen responsiveness of the prolactin gene. Molecular Endocrinology 8 1742-1749.

Paech K, Webb P, Kuiper GJM, Nilsson S, Gustafsson JA, Kushner PJ \& Scanlan TS 1997 Differential ligand activation of estrogen receptors ER $\alpha$ and ER $\beta$ at AP-1 sites. Science 277 1508-1510.

Parker MG 1993 Action of 'pure' antiestrogens in inhibiting estrogen receptor action. Breast Cancer Research and Treatment 26 131-137.

Petit PX, Susin SA, Zamzami N, Mignotte B \& Kroemer G 1996 Mitochondria and programmed cell death: back to the future. FEBS Letters 396 7-13.

Petronilli V, Cola C \& Bernardi P 1993 Modulation of the mitochondrial cyclosporin A-sensitive permeability transition pore. II. The minimal requirements for pore induction underscore a key role for transmembrane electrical potential, matrix $\mathrm{pH}$, and matrix $\mathrm{Ca}^{2+}$. Journal of Biological Chemistry 268 1011-1016.

Raffray M \& Cohen GM 1997 Apoptosis and necrosis in toxicology: a continuim or distinct modes of cell death? Pharmacology and Therapeutics 75 153-177.
Ramasara T 1982 Generation of $\mathrm{H}_{2} \mathrm{O}_{2}$ in biomembranes. Biochemica et Biophysica Acta 694 69-93.

Ramkumar T \& Adler S 1995 Differential positive and negative transcriptional regulation by tamoxifen. Endocrinology 136 536-542.

Reed JC 1997 Double identity for proteins of the Bcl-2 family. Nature $387773-776$.

Riss TL \& Sirbasku DA 1989 Rat pituitary cells in serum free culture. II Serum factor and thyroid hormone requirements for estrogen responsive growth. In Vitro 25 136-142.

Schmidt KN, Amstad P, Cerutti P \& Baeuerle PA 1986 Identification of hydrogen peroxide as the relevant messenger in the activation pathway of transcription factor NF- $\mathrm{\kappa B}$. In Biological Reactive Intermediates $V$, pp 63-68. Ed R Snyder. New York: Plenum Press.

Schwartzman RA \& Cidlowski JA 1993 Apoptosis: the biochemistry and molecular biology of programmed cell death. Endocrine Reviews 14 133-151.

Sims JL, Berger SJ \& Berger NA 1983 Poly(ADP-ribose) polymerase inhibitors preserve nicotinamide adenine dinucleotide and adenosine 5 -triphosphate pools in DNA-damaged cells: mechanism of stimulation of unscheduled DNA synthesis. Biochemistry 22 $5188-5194$.

Slater TF, Sawyer B \& Sträuli U 1963 Studies on succinatetetrazolium reductase systems III. Points of coupling of four different tetrazolium salts. Biochemica et Biophysica Acta 77 383-393.

Van Itallie CM \& Dannies PS 1988 Estrogen induces accumulation of the mitochondrial ribonucleic acid for subunit II of cytochrome oxidase in pituitary tumour cells. Molecular Endocrinology 2 332-337.

Wakeling AE, Dukes M \& Bowler J 1991 A potent specific pure antiestrogen with clinical potential. Cancer Research 51 3867-3873.

Wang TTY \& Phang JM 1995 Effects of estrogen on apoptotic pathways in human breast cancer cell line MCF-7. Cancer Research 55 2487-2489.

Wiklund JA \& Gorski J 1982 Genetic differences in estrogen-induced deoxyribonucleic acid synthesis in the rat pituitary: correlations with pituitary tumour susceptibility. Endocrinology 111 1140-1149.

Yang J, Liu X, Bhalla K, Kim CN, Ibrado AM, Cai J, Peng TI, Jones DP \& Wang X 1997 Prevention of apoptosis by Bcl-2: release of cytochrome c from mitochondria blocked. Science $\mathbf{2 7 5}$ $1129-1132$.

Zamzami N, Hirsch T, Dallaporta B, Petit PX \& Kroemer G 1997 Mitochondrial implication in accidental and programmed cell death: apoptosis and necrosis. Journal of Bioenergetics and Biomembranes 29 185-193.

Zhivotovsky B, Orrenius S, Brustugun OT \& Døskeland SO 1998 Injected cytochrome c induces apoptosis. Nature $391449-450$.

Zhou-Li F, Albaladejo V, Joly-Pharaboz MO, Nicolas B \& Andre J 1992 Antiestrogens prevent the stimulatory effects of L-triiodothyronine on cell proliferation. Endocrinology 130 1145-1152.

Zoratti M \& Szabò I 1995 The mitochondrial permeability transition. Biochemica et Biophysica Acta 1241 139-176.

Received 28 August 1998

Accepted 3 December 1998 